\title{
Allocative Efficiency of Rice Production in Cross River State, Nigeria: A Production Function Approach
}

\author{
Ajoma, $C^{1}$., Ezihe,J.A.C ${ }^{2}$. and Odoemenem, I.U ${ }^{3}$. \\ Department of Agricultural Economics, College of Agricultural Economics and Extension University of \\ Agriculture, Makurdi, Nigeria
}

\begin{abstract}
The paper analyzed the efficiency of resource utilization in rice production in Cross River State, Nigeria. The population of this study comprises of all the small scale rice farmers in Cross River State. A multistage sampling technique was used to collect data from 219 rice farmers using a well structured questionnaire. Cobb-Douglas Stochastic production frontier function and marginal analysis were used for the analysis. The result revealed that there was gross inefficiency in the allocation of productive resources among small scale rice farmers in the study areas. Apart from fertilizer which had allocative efficiency index of 0.50, inputs such as farm size(282.90), labour(1.97), seed(241.80), pesticide(223.12), and herbicide(194.05) were under-utilized implying sub-optimal resource allocation in rice farming among small scale rice farmers in Cross River State, Nigeria. The result further revealed that 99.6 percent adjustment is required for optimum utilization in farm size, seed and pesticide, 49.2 percent required for labour, 99.5 percent required for herbicide. Conversely fertilizer was over-utilized and required 98.2 percent reduction. The results equally revealed that cost of fertilizer(99.1percent), pest and disease attack(96.3percent), cost of labour(95.9percent) and weed control(90.0percent) were found to be the major constraint of rice farmers in the study area. The study recommends that In order to improve efficiency in resource allocation in rice production more of farm size, labour, seed, pesticide and herbicide should be utilized.
\end{abstract}

Keywords: Allocative efficiency, Cross River, Resource allocation, rice farmers, rice production

\section{Introduction}

Agriculture constitutes a significant sector of Nigeria's economy. The sector plays a very significant role in terms of employment of labour, food security, poverty alleviation, contribution to Gross Domestic Product (GDP) and human development chain. (Amaza and Olayemi 2002).

The contribution of agriculture to the GDP which stood at an average of 56\% between 1960 and 1964, declined to $47 \%$ in 1965, 1969 more rapidly to 32\% between 1996 and 1998 (Amaza and Olayemi 2002), and it further declined to $23 \%$ in 2013, 2014. (Nigeria National Bureau of Statistics, 2014) The agricultural sector's changing shares of GDP is partly a reflection of the relative productivity of the sector, since increased output and productivity are directly related to production efficiency (Amaza and Olayemi, 2002). In Nigeria, due to the rise in population, the demand for agricultural products is continually rising. This has resulted in the need to allocate farm resources efficiently. Therefore in order to increase food self-sufficiency and agricultural production, efficient allocation of the meager resources at the farmer's disposal should be encouraged.(Ntuokwa and James, 2012).

In Nigeria, rice is one of the important food crops that has attained a staple food status and also became a major source of calories for the urban poor (Idiong 2007). Furthermore, it has been emphasized that rice is not only a key source of food, but also a major employer of labour and source of income for the poor. In rice producing areas, the enterprise provides employment for more than $80 \%$ of the inhabitants in various activities along the production/distribution chain from cultivation to consumption (Ogundele and Okoruwa, 2006). Rice is grown virtually in all the agro-ecological zones in Nigeria (Akande, 2003). This is because; Nigeria has ideal climatic conditions which are akin to that of South East Asia where the crop is produced for export. The land area that could be cultivated is roughly 4.7 million hectares, but only 2.7 million hectares were harvested to rice. Although, the paddy harvest rose from under one million tonnes in 1970s to 4.2 million tonnes in 2010, yet, production has not kept pace with demand (Diagne et al. 2011). The estimated annual consumption of rice is put at five million metric tonnes. This inability of the Nigerian rice sector to match the domestic demand has led the country in expending billions of Naira on the importation of rice into the country. Nigeria imports on average 1.7 million tonnes of white rice annually, making the country as the world's second largest rice importer (Diagne et al., 2011). However, domestic supply of rice has continued to fall short of demand and importation is undertaken to make up the shortfall.

Recently the federal government of Nigeria had announced her plans to ban the importation of rice by 2015. According to the government, the country must be self-sufficient in rice in a manner that grows agricultural sectors to create jobs. Therefore, it was going ahead to ensure the ban on rice importation as from 
2015, at which time the nation would have attained self- sufficiency in rice production in line with the rice implementation plan (Osagie, 2014). In line with the new policies in Rice sub-sector, it becomes appropriate to examine the allocative efficiency of Rice farming in responding to favourable policy environment in Rice production.

\subsection{Theory of Allocative Efficiency}

\section{Theoretical Framework}

Allocative efficiency is a measure of how an enterprise uses production inputs optimally in the right combination to maximize profits (Inoni, 2007). Thus, the allocatively efficient level of production is where the farm operates at the least-cost combination of inputs. Most studies have been using gains obtained by varying the input ratios based on assumptions about the future price structure of products say maize output and factor markets. This study follows Chukwuji, et al., (2006) reviewed assumptions used by farmers to allocate resources for profit maximization. Such assumptions included, farmers choose the best combination (low costs) of inputs to produce profit maximizing output level; there is perfect competition in input and output markets; producers are price takers and assumed to have perfect market information; all inputs are of the same quality from all producers in the market.

Allocative efficiency can also be defined as the ratio between total costs of producing a unit of output using actual factor proportions in a technically efficient manner, and total costs of producing a unit of output using optimal factor proportions in a technically efficient manner (Inoni, 2007). Thus for the farm to maximize profit, under perfectly competitive markets, which requires that the extra revenue (Marginal Value Product) generated from the employment of an extra unit of a resource must be equal to its unit cost (Marginal Cost = unit price of input) (Chukwuji, et al., 2006). In summary if the farm is to allocate resources efficiently and maximize its profits, the condition of MVP $=$ MC should be achieved.

\subsection{Concept of Production Efficiency}

The efficient method of producing a product is that which uses the least amount of resources to get a given amount of the product. The analysis of efficiency is generally associated with the possibility of farms producing a certain optimal level of output from a given bundle of resources or certain level of output at least cost. Increase in production and productivity are direct consequences of efficiency input combination given the available technology. (Ogundari and $\mathrm{Ojo}$,2007).The concept of productive efficiency was first introduced by Michael Farrell (1957) who argued that there were two components of efficiency: technical efficiency (TE) and allocative efficiency (AE). According to Farrell's methodology, economic efficiency $(E E)$ is equal to the product of $T E$ and $A E$ where, $T E$ is associated with the ability to produce on the frontier isoquant, while $A E$ refers to the ability to produce at a given level of output using the cost-minimizing input ratios. In other words, technical inefficiency reflects deviations from the frontier isoquant, and allocative inefficiency is related to deviations from the minimum cost input ratios. Thus, $E E$ is defined as the capacity of a firm to produce a predetermined quantity of output at minimum cost for a given level of technology (Farrell 1957; Kopp and Diewert 1982). An economically efficient firm is the one which is technically as well as allocatively efficient.

The basis of a frontier function can be illustrated with a farm using $\mathrm{n}$ inputs $\left(X_{1}, X_{2}, \ldots . ., X_{n}\right)$ to produce output $Y$. Efficient transformation of inputs into output is characterized by the production function $\mathrm{f}(X i)$, which shows the maximum output obtainable from various input vectors. The stochastic frontier production function assumes the presence of technical inefficiency of production. Hence, the function is defined as:

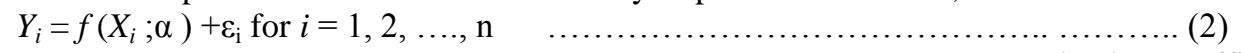

Whereby $Y i$ is the output of farmer $i, X i$ are the input variables, $\alpha i$ are production coefficients and $\varepsilon$ is the error term that is composed of two elements, that is:

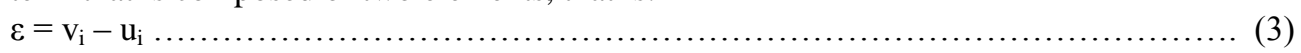

Where $v_{i}$ is the stochastic error which is assumed to be identically, independently and normally distributed with zero mean and a constant variance $\left(\sigma \mathrm{v}^{2}\right)$. The other second component $\left(\mathrm{u}_{\mathrm{i}}\right)$ is a one-sided error term which is independent of $\mathrm{v}_{\mathrm{i}}$ and is normally distributed with zero mean and a constant variance $\left(\sigma \mathrm{u}^{2}\right)$, allowing the actual production to fall below the frontier but without attributing all short falls in output from the frontier as inefficiency.

We follow Jondrow et al. (1982) that the technical efficiency estimation is given by the mean of the conditional distribution of inefficiency term $\mathrm{u}_{\mathrm{i}}$ given $\varepsilon$; and thus is defined by:

$$
E\left(u_{i} \backslash \varepsilon_{i}\right)=\frac{\sigma_{u}-\sigma_{v}}{\sigma}-\left[\frac{f\left(\varepsilon_{j} \lambda \backslash \sigma\right)}{1-F\left(\varepsilon i_{i} \lambda \backslash \sigma\right)}-\frac{\varepsilon_{i} \lambda}{\sigma}\right]
$$

here $\lambda=\sigma_{\mathrm{u}} / \sigma_{\mathrm{v}}, \sigma^{2}=\sigma_{\mathrm{u}}{ }^{2}+\sigma_{\mathrm{v}}{ }^{2}$ while $f$ and $\mathrm{F}$ stand for the standard normal density and cumulative distribution function, respectively evaluated at $\varepsilon j \lambda / \sigma$. We define the farm-specific technical efficiency in terms of observed output $(\mathrm{Yi})$ to the corresponding frontier output $\left(\mathrm{Yi}^{*}\right)$ using the existing technology derived from equation (4) above as: 


$$
T E_{i}=\frac{Y_{i}}{Y_{i}^{*}}=\frac{E\left(Y_{i} \backslash u_{i}, X_{i}\right.}{E\left(Y_{i} \backslash u_{i}=0, X_{i}\right.}=e^{\left[E\left(u_{i} \backslash \varepsilon_{i}\right)\right]}
$$

The values of TE range between o and 1 where the latter shows that the farm is fully efficient.

In order to estimate farm level overall economic efficiency, we specify the stochastic frontier cost functions model as follows:

$\mathrm{Ci}=\mathrm{h}(\mathrm{Yi}, \mathrm{Pi} ; \alpha)+\varepsilon \mathrm{i}$ where $\mathrm{i}$ varies from 1 to $\mathrm{n}$.

Here $\mathrm{Ci}$ is the total production cost, $\mathrm{Yi}$ stands for output produced, $\mathrm{Pi}$ is cost of input, $\alpha$ represents the parameters of the cost function to be estimated and $\varepsilon i$ is the error term that is composed of two elements, that is:

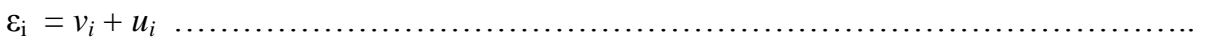

Here vi and ui are as defined earlier. Since, inefficiencies are assumed to add to costs, error components, therefore, have positive signs.

We define the farm specific economic efficiency as the ratio of minimum observed total production $\operatorname{cost}\left(\mathrm{C}^{*}\right)$ to actual total production cost $(\mathrm{C})$ using the result of equation 4 above. That is:

$E E=\frac{\mathrm{C}^{*}}{\mathrm{C}}=\frac{\mathrm{E}\left(\mathrm{C}_{\mathrm{i}} \mathrm{u}_{\mathrm{i}}=0, Y_{i, P} P\right)=e^{\left[E\left(u \backslash \varepsilon_{\mathrm{i}}\right)\right]}}{\mathrm{E}\left(\mathrm{C}_{\mathrm{i}} \mathrm{i} \mathrm{u}_{\mathrm{i}}, Y_{i,} P\right)}$

The EE also has values in the range of 0 and 1. Thus, a measure of farm specific allocation efficiency is obtained from technical and economic efficiencies estimated as follows:

$\mathrm{AE}=\mathrm{EE} / \mathrm{TE}$.

This implies that $0 \leq \mathrm{AE} \leq 1$.

\section{Methodology}

This study was conducted in Cross River State. The present state came into being in September 1987 when the old Cross River State was split into Akwa Ibom and Cross River State. There are eighteen Local Government Areas (LGAs) in the state and three Agricultural Development Program (ADP) zones. Zone one comprises of Calabar Municipality, Calabar South, Akamkpa, Biase, Odukpani, Akpabuyo and Bakassi LGAs. Zone two comprises of Yakurr, Abi, Obubra, Ikom, Etung and Boki LGAs. Zone three comprises of Ogoja, Obudu, Bekwara, Obanliku and Yala LGAs. Cross River State lies between latitude $5^{0} 32^{\prime}$ and $4^{0} 27^{\prime}$ North and longitude $7^{0} 50^{\prime}$ and $9^{0} 28^{\prime}$ East; situated within the tropics and shares a common boundary with the Republic of Cameroon in the East, Benue State in the North, Abia and Anambra State in the West, Ebonyi State in the North West and Akwa Ibom State in the South. (www.crossriverstate.gov.ng).

The population of the study comprised all the small scale rice farmers in the three agricultural development programme (ADP) zones in Cross Rivers State, which include: zone one(Cross River South), zone two (Cross River Central), zone three (Cross River North). A multistage random sampling technique was adopted for this study. The first stage involved the purposive selection of four local government areas where rice is produced in relatively large quantities, which include Biase, Obubra, Yala and Ogoja local government areas. The second stage of the sampling process involved a random selection of two rice producing communities in each of the local government areas. The communities were Ofodua, Ovumbogha, Adim, Abini, Yache, Igbeku, Nwang and Bansara. The third stage was drawn up with the help of CRADP by identifying registered small scale rice farmers in the eight rice producing communities. The fourth stage was a proportional sample of 8 percent of small scale rice farmers was randomly selected in each community. Thus a total of 237 small scale rice farmers were selected for the study. However, only 219 of the questionnaire were retrieved. The sample size selection is presented more explicitly in table 1. Data for the study were collected from primary sources. Primary data were collected through a well structured questionnaire which was administered to the sample rice farmers with the aid of enumerators who served as extension officers.

\subsection{Technical Efficiency Model}

The stochastic frontier production function (SFPF) will be used to analyse the efficiency of resource in the production of rice in the study area. A stochastic production frontier is defined in terms of the maximum output given the technology available to the farm. This is specified by the Cobb-Douglas frontier production function defined by Coelli (1994) as :

$\mathrm{LnY}=\beta_{0}+\beta_{1} \operatorname{LnX}_{1}+\beta_{2} \operatorname{LnX}_{2}+\beta_{3} \operatorname{LnX}{ }_{3}+\beta_{4} \operatorname{LnX} X_{4}+\beta_{5} \operatorname{LnX}{ }_{5}+\beta_{6} \operatorname{LnX}_{6}+\mathrm{V}_{\mathrm{i}^{-}} \mathrm{U}_{\mathrm{i}}$

Where:

$\mathrm{Ln}=$ Natural logarithm to base 10

$\mathrm{Y}=$ Total rice output of the farmer in kilogram per hectare $(\mathrm{kg} / \mathrm{ha})$.

$\beta \mathrm{s}=$ the parameters to be estimated.

$\mathrm{X}_{1}=$ Farm size in hectares

$\mathrm{X}_{2}=$ Labour used measured in man days per hectare

$\mathrm{X}_{3}=$ Quantity of improved or local seed $(\mathrm{kg} / \mathrm{ha})$

$\mathrm{X}_{4}=$ quantity of fertilizer applied measured in kilogram per hectare $(\mathrm{kg} / \mathrm{ha})$

$\mathrm{X}_{5}=$ Quantity of pesticides used measured in litres per hectare (litres/ha)

DOI: 10.9790/2380-0908023238 www.iosrjournals.org


$\mathrm{X}_{6}=$ Quantity of herbicides used measured in litres per hectare (litres/ha)

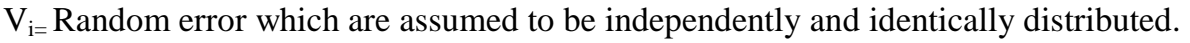

$\mathrm{U}_{\mathrm{i}=}$ Non negative random variable associated with technical inefficiency of production.

\subsection{Allocative Efficiency Model}

The allocative efficiency model is achieved when a given input is used to maximize profit given its price. Therefore allocative efficiency is achieved when input is used in such a way that marginal value product from the input equals it price or marginal cost.

The average physical product APP is calculated by;

APPi $=\frac{Y}{X}$.

Where $\mathrm{Y}$ and $\mathrm{X}$ are the mean of the output and inputs respectively.

The marginal physical product MPP was given as;

MPPxi $=$ bi. APPi where bi is the elasticity of the various inputs used. .14

The Marginal value product (MVP) of production is given as:

MVP = MPPxi. PYi...

$\mathrm{PY}$ is the output (paddy) price

Pxi is the price per unit of resource input used

Marginal factor cost (MFC) is the price for each inputs used estimated as average acquisition cost.

$\mathrm{r}=\frac{M V P}{M F C}$.

Where:

MVP = marginal value product

MFC $=$ marginal factor cost

$\mathrm{R}=$ numerical constant

In a way to substitute the efficiency hypothesis, focus was based on the estimated value of $\mathrm{R}$ and its closeness to unity. Allocative Efficiency is attained if:

MVP $=$ MFC

The relative percentage change in MVP (marginal value product adjustment) of each resource required in order to obtain optimal allocation of resources. i.e. $\mathrm{r}=1$ or MVP=MFC which was estimated using equation below:

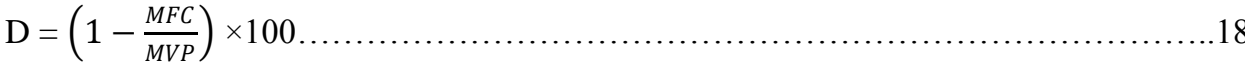

Where:

$\mathrm{D}=$ absolute value of percentage change in MVP of each resource.

Economic optimum occurs where MVP=MFC. If $r \neq 1$, it suggests that resources are not efficiently utilized. Adjustment could therefore be done in the quantity of inputs employed and costs in the production process to restore $\mathrm{r}=1$.

\section{Results And Discussion}

\subsection{Estimate of the Parameters in the Stochastic Production Frontier Function}

The maximum likelihood estimates (MLE) of the Cobb-Douglas stochastic production frontier model for rice production are presented in table 3. The results revealed the presence of technical inefficiency among rice farmers in the study area based on the significance of gamma and the Likelihood Ratio $(\lambda)$ test. The $\lambda$ test which has mixed Chi-square $\left(\alpha^{2}\right)$ distribution stood at 48.69 , while the critical value of chi-square at $0.05 \%$ confidence interval and 9 degree of freedom, $\alpha^{2}(0.05,9)=3.33$. Thus the null hypothesis of no inefficiency effects $(\gamma=0)$ was rejected. This means that the traditional frontier model estimated with ordinary least square, (which is estimated without the inefficiency effects), was not the adequate representation of the data, hence Cobb-Douglas stochastic frontier model which described farm specific inefficiency effects fits this data better. This agrees with the report of Tsue and Akande (2010), Ogundari and Ojo (2006) and Himayatullah and Imranullah (2011). The coefficient of the sigma square $\left(\sigma^{2}\right)$ was less than unit $(0.299)$ and significant at 1 percent level of probability for rice farmers indicating goodness of fit and correctness of the specified distribution assumption of the composite error term

Gamma $(\gamma)$ estimate of this model (0.71) was statistically significant at 1 percent. This implies that the one-sided random inefficiency component strongly dominates the measurements error and other random disturbance indicating that about 71 percent of variation in actual output from maximum output (production frontier) between farms mainly arose from differences in farmers' practice and management rather than random variability. The sum of the coefficients, which is a measure of return to scale in rice production, was less than unity $(0.70)$ indicating a positive decreasing return to scale. This implies that an increase in quantity of all inputs employed in the production of rice result in less than proportionate increase in quantity of output produced. Thus rice farmers in the study area can expand their production through additional use of inputs. 


\subsection{Elasticity of production and return to scale}

The result revealed that the coefficient of all the variables in the production function were positive and conformed with a priori expectations indicating that the estimated production function is an increasing function. The coefficient of farm size, labour, quantity of seed and quantity of herbicide are statistically significant. The coefficient of farm size (0.21) was positive and highly significant at 1 percent level. This indicates that farm size $\left(\mathrm{x}_{1}\right)$ has a positive relationship with output. This implies that a unit increase in the variable under static condition of other explanatory variables result in increased output level by 0.21 percent. This result is in conformity with Ntuokwa and james (2012). The estimated coefficient for labour was also positive and significant at 1 percent level. Rice production is labour intensive from cultivation to harvesting. Thus, the 0.25 elasticity of labour implies that a 1 percent increase in labour, certeris paripus will lead to an increase of 0.25 percent in the farm output and vice versa. This shows the importance of family labour in the area. The finding agrees with several studies (Ntuokwa and James 2012. Himayatullah and Imranullah 2011; and Umoh, 2006).

The coefficient of quantity of seed(0.12) was positive and significant at 5 percent level. This indicates that higher seed rate or improved seed rate would result in high yield except where there is over crowding leading to competition for available nutrient which will consequently lead to lower yield. This result also agrees with Ntuokwa and James,(2012). Furthermore, the coefficient of fertilizer (0.02) and pesticide (0.02) were positive which conform to a priori expectation but were not statistically significant, meaning that increase in any of this would result in increase in output but not significantly. The coefficient of quantity of herbicide (0.085) was positive and statistically significant at 10 percent level. This implies that an increase in the use of herbicide would result in increase in output certeris paripus.

Table 1 presentation of the maximum likelihood estimate of the parameters in stochastic frontier analysis $(n=219)$

\begin{tabular}{|c|c|c|c|}
\hline Variables & Parameters & Coefficient & t-ratio \\
\hline \multicolumn{4}{|l|}{ Production Factors } \\
\hline Constant & $\mathrm{X}_{0}$ & 5.810 & $12.397 *$ \\
\hline Farm Size & $\mathrm{X}_{1}$ & 0.211 & $3.514 *$ \\
\hline Labour & $\mathrm{X}_{2}$ & 0.247 & $4.197 *$ \\
\hline Quantity of seed & $\mathrm{X}_{3}$ & 0.115 & $2.017 * *$ \\
\hline Quantity of fertilizer & $\mathrm{X}_{4}$ & 0.016 & 0.928 \\
\hline Quantity of pesticide & $\mathrm{X}_{5}$ & 0.021 & 0.723 \\
\hline Quantity of herbicide & $\mathrm{X}_{6}$ & 0.085 & $1.689 * * *$ \\
\hline Sigma-square & $\Sigma$ & 0.299 & $4.789 *$ \\
\hline Gamma & $\Gamma$ & 0.707 & $6.187 *$ \\
\hline Likelihood function & $\Lambda$ & -140.68 & \\
\hline LR test of one sided error & & 48.69 & \\
\hline $\mathrm{X}_{0.05}^{2}=3.33$ & & & \\
\hline
\end{tabular}

Note: $*, * *$ and $* * *$ denote t-test significant at $1 \%, 5 \%$ and $10 \%$ levels respectivel

\subsection{Estimation of allocative efficiency of rice farmers in Cross River State.}

The results of the estimates of allocative efficiencies in rice production are shown in table 7. However, the estimation of resource-use efficiency required the determination of parameters such as marginal physical product (MPP), marginal factor cost (MFC), and marginal value product (MVP). The marginal factor cost of each input was determined as the average farm cost of an input per unit output. Chukwuji et al. (2006). Estimate of allocative efficiency of production resources employed in rice farming were 282.90, 1.97, 241.80, 0.50, 223.12, and 194.05 respectively for farm size, labour, seed, fertilizer, pesticide and herbicide. The indices indicate that apart from fertilizer which was over-utilized, all other resources were under-utilized, implying suboptimal resource allocation in rice farming in Cross River state, Nigeria. Inadequate, and timely access to production credit by many farmers may be responsible for the under-utilization of farm size, labour, seed, pesticide, and herbicide in the production process. This condition point out that a unit increase in each of these under-utilized input would increase the value of output. The result further revealed that fertilizer was overutilized. This may be because government subsidized fertilizer and distributed it on time, and also because the farmer need more output they decided to use more of fertilizer without putting other inputs into consideration. This finding disagrees with Inoni (2007) who found that apart from fertilizer, all other inputs were over-utilized. But agrees with sani et al. (2010) who found that all inputs (fertilizer, labour and land were under-utilized. Hence, since the use of farm size, labour, seed, pesticides and herbicides were under-utilized; farmers could increase their utilization in order to improve their allocative efficiency.

It should be noted that the MVPs of the inputs were not negative indicating that rice farmers still use these resources within the economically rational range even though they were not optimally used. A similar study conducted by Abiola et al. (2016) on resource-use and allocative efficiency of paddy rice production in 
Mada, Malaysia, revealed that farmers were under-utilized in the use of pesticide and herbicide and were overutilized in the use of seed, fertilizer and labour respectively.

Table 2 indices of allocative efficiency of resources utilized in rice production

\begin{tabular}{|l|l|l|l|l|l|l|}
\hline Variables & Coefficient & APP & MPP & MVP & MFC & AE \\
\hline Farm size & 0.211 & 1840.79 & 388.41 & 2908196.57 & 10279.94 & 282.90 \\
\hline Labour & 0.247 & 1.12 & 0.28 & 2096.48 & 1064.88 & 1.97 \\
\hline Seed & 0.115 & 81.43 & 9.36 & 70082.44 & 289.84 & 241.80 \\
\hline Fertilizer & 0.016 & 20.61 & 0.33 & 2470.86 & 4898.17 & 0.50 \\
\hline Pesticide & 0.021 & 1298.73 & 27.27 & 204182.49 & 915.18 & 223.12 \\
\hline Herbicide & 0.085 & 293.93 & 24.98 & 187036.25 & 963.84 & 194.05 \\
\hline
\end{tabular}

Note: $\mathrm{Px}=$ Input unit prices, $\mathrm{Py}=$ output selling price $(\mathrm{N} 787.44 / \mathrm{kg}), \mathrm{MVP}=$ Marginal value product, $\mathrm{AE}=$ Allocative Efficiency level.

\subsection{Percentage adjustment in marginal value product}

The result in table 8 shows the percentage adjustment in marginal value product for optimum utilization of inputs. Optimum utilization of inputs requires that marginal value product be equal to input unit price, that is marginal factor cost (MVP=MFC). 99.6 percent adjustment is required for optimum utilization in farm size, 49.2 percent required for labour, 99.6 percent required for seed, 99.6 percent required for pesticide and 99.5 percent is required for herbicide. Conversely fertilizer was over-utilized and required 98.2 percent reduction. The result indicates that a lot need to be done to bridge the gap of optimum use of the resources in the study area. This requires the efforts of farmers, marketers, government and non-governmental agencies in charge with the agricultural sector. This result agrees with Sani et al. (2010) who found that fertilizer, labour, and land required an adjustment of 85.7 percent, 83.3 percent, and 69.0 percent respectively for optimum utilization. The result also agrees with Abiola et al. (2016) who found that pesticide and herbicide required to be adjusted with 10.62 percent, and 34.78 percent respectively.

Table 3 Marginal value product adjustment

\begin{tabular}{|l|l|l|l|l|}
\hline Variables & MVP & MFC & Efficiency Gap & Percentage adjustment \\
\hline Farm size & 2908196.57 & 10279.94 & 2897916.63 & 99.6 \\
\hline Labour & 2096.48 & 1064.88 & 1031.60 & 49.2 \\
\hline Seed & 70082.44 & 289.84 & 69792.60 & 99.6 \\
\hline Fertilizer & 2470.86 & 4898.17 & -2427.31 & -98.2 \\
\hline Pesticide & 204182.49 & 915.18 & 203267.31 & 99.6 \\
\hline Herbicide & 187036.25 & 963.84 & 17739.41 & 99.5 \\
\hline
\end{tabular}

Source: Field Survey, 2016

\subsection{Constraints Associated with Rice Production in the Study Area}

The distribution of respondents with regards to the constraints militating against rice production in the study area shows that the major rice production constraints faced by farmers in the study area were; high cost of fertilizer ( 99.1 percent), pest and disease attack ( 96.3 percent), high cost of labour (95.9 percent), weeds control (90.0 percent), inadequate capital (89.0 percent), inadequate supply of farm input and lack of modern farm equipment ( 86.3 percent each), lack of credit facilities ( 84.5 percent), poor access roads ( 83.1 percent), risk and uncertainties (79.0 percent) and land tenure system (78.1 percent). This implies that high cost of fertilizer, pest and disease attack, and high cost of labour as also pointed out by Odoemenem and Inakwu (2011), constitute the major production constraints farmers in the study area faced. This finding also agrees with the finding of Ohen and Ajah (2014), who found out that lack of access to finance was a serious problem encountered by rice farmers in the study area.

Table 4 Constraints Faced by Rice Farmers in Cross River State

\begin{tabular}{|l|l|l|l|}
\hline Constraints & Frequency & Percentages & Ranking based on \% \\
\hline High cost of fertilizer & 217 & $99.1^{*}$ & 1 \\
\hline Pest and disease attack & 211 & $96.3^{*}$ & 2 \\
\hline High cost of labour & 210 & $95.9^{*}$ & 3 \\
\hline Weeds control & 197 & $90.0^{*}$ & 4 \\
\hline Inadequate capital & 195 & $89.0^{*}$ & 5 \\
\hline Inadequate supply of farm input & 189 & $86.3^{*}$ & 6 \\
\hline Lack of modern farm equipment & 189 & $86.3^{*}$ & 7 \\
\hline Lack of credit facilities & 185 & $84.5^{*}$ & 8 \\
\hline Poor access road & 182 & $83.1^{*}$ & 9 \\
\hline Risk and uncertainties & 173 & $79.0^{*}$ & 10 \\
\hline Land tenure system & 171 & $78.1^{*}$ & 11 \\
\hline
\end{tabular}

Source: Field Survey, 2016 multiple responses recorded * 


\section{Conclusion}

This study was undertaken to analyze the allocative efficiency of rice production in Cross River State, Nigeria. The sustainability of increased rice production in the state under study and Nigeria at large, depend on efficient use of resources in producing the crop by farmers. The result revealed that farm size, labour, quantity of seed and quantity of fertilizer had positive and significant influence on rice production in a production pattern that exhibit decreasing return to scale (0.70). Also the results indicated that there was gross inefficiency in the allocation of productive resources among rice farmers in the study area. Apart from fertilizer which had allocative efficiency index of 0.50 , inputs such as farm size, labour, seed, pesticide and herbicide were underutilized implying sub-optimal resource allocation in rice farming in Cross River state, Nigeria. The results further revealed that the major constraints faced by rice farmers in the study area include: high cost of fertilizer, pest and disease attack, high cost of labour, weed control, inadequate capital, inadequate supply of farm input, lack of modern farm equipment, lack of credit facilities and poor access road.

\section{Recommendations}

In order to improve efficiency in resource allocation in rice production, it is recommended that input such as farm size, labour, seed, pesticide and herbicide should be made available by subsidizing the price by government and non-governmental organization so that farmers can increase the use of these input.

\section{References}

[1]. Abiola, O.A., Mad Nasir, S., Alias, R. and Ismail, A.L. (2016). Resource-Use and Allocative Efficiency of Rice Production in Mada, Malaysia. Journal of Economics and Sustainable Development. Vol. 7(1)

[2]. Akande, T. (2003). "An Overview of Nigerian Rice Economy" Monography published by the Nigerian Institution of Social and Economic Research (NISER), Ibandan.

[3]. Amaza, P.S. and J.K. Olayemi. (2002). Analysis of Technical Inefficiency in Food Crop Production in Gombe State,Nigeria. Applied Economic Letters 9:51-54.

[4]. Coelli, T.J. (1994). A Guide to Frontier 4.1: A computer programme for stochastic frontier Production andcostfunction estimation. Department of Econometrics, University Of New England. Armidale

[5]. Chukwuji, C.O. Inoni, O.E. Ogisi, D.O. and Oyaide, W.J. (2006). “ A Quantitative Determination of Allocative Efficiency in Broiler Production in Delta State, Nigeria. Agriculturae Conspectus Scientific us, vol. 71(1):21-26

[6]. Diagne, A., Bamba, I., Manful, J. and Ajayi, O.M. (2011). Historic opportunities for rice growers InNigeria.Inter-reseaux development rural. Retrieved from www.interreseaux.com on 12/7/14.

[7]. Farrel, C.J.(1957). The Measuerment of the production efficiency. Journal of Royal Statistics Society Series, 120: 253-290.

[8]. Himayatullah, K. and Imranullah, S. (2011). Measurement of Technical, Allocative And Economic Efficiency of Tomato Farms in Northern Pakistan. International Conference on Management, Economics and Social Sciences (ICMESS’ 2011).

[9]. Idiong .I.C. (2007). Estimation of Farm Level Technical Efficiency in Small scale Swamp Rice Production in Cross River State of Nigeria: A Stochastic Frontier Approach. World Journal of Agricultural Sciences 3(5): 653-658.

[10]. Inoni, O.E. (2007). Allocative Efficiency in Pond Fish Production in Delta State, Nigeria. A Production Function Approach AgriculturaTropica Et Subtropica vol. 40(4)

[11]. Jondrow J., Lovell C.A.K., Ivan S.M. and Schmidt P. (1982). On the Estimation of Technical inefficiency in the Stochastic Frontier Production Function Model. Journal of Econometrics vol. (19) pp. 233-238

[12]. Kopp, R.J. and W.E. Diewert. (1982). Frontier Production Function Estimates for Steam Electric Generation. A comparative Analysis Southern Economic Journal. 47. Pp. 1049-1059.

[13]. Ntuokwa, E.T. and James, H.E.(2012). Analysis of Resource Use Efficiency in Yam Production InYakurrLocal Government Area of Cross River State, Nigeria. Agricultural Journal 7(5): 297-304.

[14]. Odoemenem, I.U. and Inakwu, J.A. (2011). Economic Analysis of Rice Production in Cross River State, Nigeria. Journal of Development and Agricultural Economics, Vol, 3(9):469-474.

[15]. Ogundele, O.O. and Okoruwa, V.O. (2006). Technical Efficiency Differential in Rice Production Technologies in Nigeria. AER Research Paper 154, Africa Economic Research Consortium, Nairobi.

[16]. Ogundari, K. and Ojo, S.O. (2007). "Economic Efficiency of Small Scale Food Crop Production in Nigeria. A Stochastic Frontier Approach" Journal of Social Science, vol. 14(2) pp. 123-130

[17]. Ohen, S.B. and Ajah, E.A. (2014). Cost and return analysis in small scale rice production in Cross River State, Nigeria. International Research Journal of Agricultural Science And Soil Science. (ISSN: 2251-0044). Vol, 5(1) pp.22-27.

[18]. Osagie, C. (2014). Rice Import Ban and Trade Politics. THISDAY NEWS PAPER JAN 28

[19]. Sani, A., Yakubu, A.A. and Bello, H.M. (2010). Resource-Use Efficiency in Rice Production Under Small Scale Irrigation in Bunkure Local Government Area of Kano State. Nigeria journal of Basic and Applied Science. 18(2): 292-296

[20]. Tsue, P.T. and Akande, O.R. (2010). Productive Efficiency of Benue Catfish Farmers. Proceedings of International Conference on Research and Development, held at Miklin Hotel East Legon Accra Ghana. Vol. 3(19) 113-118

[21]. Umoh, G.S. (2006). Resource Use Efficiency in Urban Farming: An application of Stochastic Frontier Production Function. Int. J. Agric. Biol., 8:38-44

[22]. www.crossriverstate.gov.ng. (2014). 